\title{
Post-Reunification Restructuring and Corporate Re-bundling in the Bitterfeld- Wolfen Chemical Industry, East Germany
}

\author{
Harald Bathelt
}

\author{
Version Post-print/accepted manuscript \\ Citation Bathelt, H. (2013). Post - Reunification Restructuring and Corporate \\ (published version) $\mathrm{Re}$ - bundling in the Bitterfeld - Wolfen Chemical Industry, East \\ Germany. International Journal of Urban and Regional Research, 37(4), 1456- \\ 1485.
}

Copyright / License

Publisher's Statement

This is the peer reviewed version of the following article: [Bathelt, $\mathrm{H}$.

(2013). Post - Reunification Restructuring and Corporate Re - bundling in the Bitterfeld - Wolfen Chemical Industry, East Germany.

International Journal of Urban and Regional Research, 37(4), 1456-1485.],

which has been published in final form at:

http://onlinelibrary.wiley.com/doi/10.1111/j.1468-

2427.2012.01194.x/full

This article may be used for non-commercial purposes in accordance with Wiley Terms and Conditions for Self-Archiving.

How to cite TSpace items

Always cite the published version, so the author(s) will receive recognition through services that track citation counts, e.g. Scopus. If you need to cite the page number of the TSpace version (original manuscript or accepted manuscript) because you cannot access the published version, then cite the TSpace version in addition to the published version using the permanent URI (handle) found on the record page. 


\title{
Post-Reunification Restructuring and Corporate Re-bundling in the Bitterfeld-Wolfen Chemical Industry, East Germany
}

\author{
by \\ Harald Bathelt \\ University of Toronto, Department of Political Science and \\ Department of Geography \& Program in Planning, Sidney Smith Hall, \\ 100 St. George Street, Toronto, ON M5S 3G3, Canada; \\ E-mail: harald.bathelt@utoronto.ca; \\ URL: http://www.harald-bathelt.com
}

Paper to be re-submitted to

"International Journal of Urban and Regional Research (IJURR)" 


\title{
Post-Reunification Restructuring and Corporate Re-bundling in the Bitterfeld-Wolfen Chemical Industry, East Germany
}

\begin{abstract}
While earlier research has shown that regional restructuring processes after Reunification have led to broad de-industrialization processes in the East German chemical industry (Bathelt 2009), this paper focusses on the ways how re-bundling processes at the corporate level have stimulated adjustments to the changing economic and political environment that have led to a renewed regional development trajectory. The analysis is based on a conceptualization that analyzes diachronic processes of rupture and re-bundling by applying a bottom-up perspective of how corporate adjustments and restructuring processes generate rebundling types that manifest themselves in broader regional re-bundling scenarios. The empirical analysis focusses on a qualitative case study of Bitterfeld-Wolfen, the largest chemical industry region in East Germany. It draws on over 70 interviews with chemical firms and their suppliers/service providers conducted between 1995 and 2006. The research provides evidence that, although new firm formation has remained weak and acquisitions of chemical multinational firms have generated structures not strongly embedded in the regional economy, modernization and re-bundling process have contributed to a renewed, smaller, yet stable regional chemical industry. The analysis further shows that the associated processes depended on the roles of individual industrial leaders in the region, who acted as network builders, mobilized joint action and stimulated the development of a collective regional spirit.
\end{abstract}

Keywords: Regional restructuring; corporate re-bundling; network builders; Reunification; chemical industry; East Germany; Bitterfeld-Wolfen 


\section{Introduction}

Earlier research has shown that regional restructuring processes after German Reunification have led to broad de-industrialization processes across the manufacturing landscape in East Germany, particularly affecting in the East German chemical industry and its traditional agglomerations (Bathelt 2009). In their broad analysis of these processes, Kollmorgen (2005) and Land (2006) emphasized that the severity of restructuring was due to a double shock and related transition. It was, on the one hand, related to the transformation processes in the political and economic system in East Germany. On the other hand, globalization processes related to the Fordist crisis put pressure on regional production systems. Consequences of these shifts were massive layoffs, closures and downsizing activities of firms. Institutional support for these transitions was weak and insufficient (Thomas 2005). Associated challenges were particularly onerous in the Bitterfeld-Wolfen region, the largest chemical industry region in East Germany, which is the focus of this paper. In the post-World War II period, the chemical industry in the region developed into a strong economic sector with two so-called Kombinate - large verticallyintegrated complexes of chemical production governed through hierarchical state-led control and a labor force of more than 50,000 people. Due to unsustainable practices of economic and ecological exploitation - in terms of an unsustainable use of infrastructure, resources and production facilities - the structure of the industry could not be maintained after Reunification. Because of outdated technological standards, environmental problems and a lack of potential investors, most chemical operations were fundamentally restructured and modernized, often in conjunction with changes in ownership, governance form and organization.

The following analysis is based on a conception that draws attention to corporate rebundling processes in the aftermath of economic and political crises which may lead to new industrial development or modernization of the regional economy (Rosenfeld et al. 2007). Based on a bottom-up perspective, ideal-type scenarios of regional development are derived by the way of aggregation from corporate restructuring. Related to this conception, the first goal of this paper is to explore the firm-specific re-bundling and restructuring processes in the Bitterfeld-Wolfen chemical industry and its supplier and service industries. This leads to an investigation of how firms mobilize resources and capital for restructuring, and which strategic choices they make regarding product and market focus. Second, the paper aims to develop a typology of firms 
according to the nature of re-bundling practices, which enables us - in aggregated form - to draw conclusions regarding broader regional re-bundling paths and the prospects for future regional growth. ${ }^{1}$ While this paper focuses on a single industry in a specific East German region, its implications are much broader than this, as it is set in the context of Post-socialist restructuring. On the one hand, the conditions for regional restructuring and re-bundling are similar to the challenges in other regions and other industries in East Germany (Kollmorgen 2005; Günther and Gebhardt 2005; Land 2006), and even Eastern Europe (Grabher and Stark 1997; Pavlínek 2008). On the other hand, however, the challenges of overcoming former industrial and societal structures associated with political transformation make this a unique case in the chemical industry that is not easily comparable with regional restructuring processes in Western Europe (Greco 2004; Chapman 2005).

This paper is structured as follows: Section 2 presents the conceptual framework which connects corporate re-bundling processes with scenarios of regional re-bundling. Section 3 discusses the qualitative methodology applied in the empirical study. Section 4 then provides an overview of the post-World War II practices of economic and ecological exploitation in the Bitterfeld-Wolfen region that caused massive re-bundling processes after Reunification. The identified corporate re-bundling processes are discussed in the form of a typology in Section 5. Section 6 draws some conclusions, while Section 7 discusses the role of "altruistic managers" and political networks in the region's re-bundling processes in the form of an epilog. This epilog links aspects of corporate and regional re-bundling with the role of economic and political leaders and their personal networks.

${ }^{1}$ As pointed out by Zeng and Bathelt (2011), any analysis of the chemical industry has to keep in mind the specific characteristics of its products and production environment. As opposed to many other industries, close, ongoing linkages with other chemical producers tend to be standardized and do not necessarily include in-depth knowledge exchanges. Durable supplier linkages are nonetheless an important basis for joint problem-solving and incremental innovation. Related learning processes and growth effects support regional specialization and generate differentiated regional trajectories. 


\section{Conceptual Framework: Corporate Re-bundling and Regional Development}

This section develops a perspective of regional re-bundling processes that addresses the role of major economic/political crises and their impact on regional development. This conception is used to analyze the effects of the ruptures associated with Reunification in terms of economic restructuring and reconfiguration pressures in the Bitterfeld-Wolfen region. Much contemporary analysis in economic geography on related issues employs an explicitly evolutionary conception of the economy (e.g. Rigby and Essletzbichler 1997; Boschma and Lamboy 1999; Martin and Sunley 2006). While acknowledging discontinuous technological change, related studies often focus on continuity and associated lock-in processes (Grabher 1993; Dühr 1998; Hassink 2005; Martin 2010). Even though this focus helps to understand how development trajectories are formed, these analyses tend to be retrospective. Such a perspective, in turn, is less helpful in periods of crises characterized by unexpected ruptures and discontinuities and may neglect processes of regional restructuring, diversification and reconfiguration (Chapman et al. 2004).

Although studies on the evolution of industries and regions also investigate the establishment of new development paths, their focus seems to be to understand change and diversification as branching processes that build on existing competencies (Neffke et al. 2009; Boschma and Frenken 2011). While recent work combining evolutionary and resiliency conceptions has explicitly addressed the role of economic and technological discontinuities in regional economic development (Simmie and Martin 2010), the literature as a whole primarily focuses on the gradual evolution of regional economies with little discussion of how regions adapt to sudden crises (Bathelt et al. 2010). Analyses focusing on lock-in processes and development paths are useful to conduct in-retrospect analyses of long-term regional developments, yet they do not adequately address crisis-driven processes of reorganizing, modernizing and recombining existing resources and integrating them with new resources that are redeployed through sectorial shifts or result from mobilizing extra-regional resources. In order to focus on this process of recombining resources and analyzing the related negotiations, struggles and responses to structural crises, this paper employs a conception of regional ruptures and rebundling that avoids notions of continuous adjustments in technological development by integrating political and economic crises into regional analysis (Bathelt and Boggs 2003; Bathelt 2009). 
The regulationist approach provides a conceptual framework that describes why the institutional set-up of a particular mode of capitalist development can fail ensuring expanded reproduction, how structural crises in reproduction result and can be overcome, and how new economic formations may develop with stable, robust growth patterns (Boyer 1990; 2000). While crises, such as those related to Fordism and the radical socio-political change that followed German Reunification, are often national in character, this paper is interested in the regional and sectorial effects that result and focuses on those aspects of re-bundling that occur at the regional level. It is clear, of course, that successful regional re-bundling eventually depends on the wider outcomes of institutional and organizational experimentation that may restore conditions for further capital accumulation (Hirsch 1990). This latter aspect, however, goes beyond the scope of this paper.

The particular focus this paper develops with respect to structural crises is the way how such periods of failure and depression lead to reconfiguration or re-bundling processes of resources, broadly related to all sorts of physical, financial, human and social capital. This perspective builds on a resource-based and knowledge-based view of the firm (Wernerfelt 1984; Nonaka et al. 2000; Maskell 2001), suggesting that the structure of the resource and knowledge base are key in understanding a firm's capabilities and competences. Accordingly, when a structural crisis hits an economy, firms restructure their resource and knowledge base, redeploy existing resources or acquire new resources to complement existing ones. Within manufacturing industries, firms may not decide to develop specializations further by focusing on existing production branches and related skill levels. In the former case, this may be accomplished by corporate investments, acquisitions of related firms or the attraction of external investors. From a transaction-cost perspective, this leads to question as to which governance forms of transactions and production relations will develop through such reorientation and re-bundling (Williamson 1985). In the absence of uncertainty, if transactions are characterized by low factor-specificity and low frequency, new resources could be integrated into the production structure through market-based linkages. If transactions are characterized by high frequency and medium to high specificity, new resources might be accessed through extended inter-firm networks. In a situation such as Reunification, however, that is characterized by large uncertainty and the need to massively extend the resource and knowledge base to gain competitiveness, network relationships become less plausible and most new ties likely develop through vertical and horizontal integration within corporate structures. 
This is reflected in the re-bundling perspective employed in this paper paying particular tribute to Penrose's (1959: 31) work that sees resources as bundles of potential services, suggesting that it is not possible to differentiate between resources and their respective services (Mahoney and Pandian 1992). According to Penrose (1959), resources can serve a variety of purposes depending on the context in which they are employed, implying that the redeployment of resources may lead to novel technological trajectories and collectively stimulate a shift in regional development paths. As emphasized by Feldman and Francis (2006), it might be particularly important in such periods to identify entrepreneurial potential and stimulate new firm formation processes. Such activities and the individuals behind such decisions may become role models later on and stimulate further start-up and spin-off activities that trigger future growth (Storper and Walker 1989). As the crisis breaks up existing production routines, formerly occupied resources may now be available for new applications: suppliers may reorient themselves to new industry branches; employees focus on new tasks; and management may be open for new directions in innovation.

As a consequence, industrial firms and their suppliers try to find new business opportunities to overcome the crisis effects. To deal with the immediate ruptures, they may lay off workers and downsize production to reduce costs. Depending on the business opportunities they find locally, the visions of which way to go, and the availability of capital and resources from non-local sources, they are likely more open to working with technologies and in value chains they were previously unfamiliar with. As a result, more or less radical reorientation and restructuring activities take place leading to sectorial and/or geographical shifts; although there is no guarantee that this may be successful in the long-term. Firms are going through a strategic process of evaluating their capabilities in light of the changing market and industry environment. Those firms that remain try to make up for lost business or exploit new market opportunities that they were unable to address before (Bathelt and Boggs 2003).

In aggregate form, the firms' strategic decisions and responses to the crisis have strong regional consequences and shape the regional development path. Regional re-bundling activities may be more or less radical, focus on new sectors and innovations or involve few changes at all. Changes may be driven by the restructuring activities of few dominant firms; or they may follow from collective activities and the involvement of other local firms. Interactive learning and innovation processes may enable the region's actors to re-bundle technological trajectories if they are able to mobilize or redirect resources and agents towards collective action (Bathelt 2009). Of 
course, not every new bundle of economic activities has the potential to generate a new regional trajectory. Bundles, in order to have a significant impact, must have a certain scale and locally embedded linkages, both in terms of input-output relations and knowledge flows. Such developments would likely rely on anchor organizations and key individuals or economic leaders that are able to engage others in joint projects of regional development (Geißel et al. 2003; Giblin 2011).

Although emphasizing a regional perspective, the re-bundling approach does not suggest that regional resources and actors are core in the associated restructuring processes. In contrast, such processes may be triggered by external firms that employ external resources, and thus depend on the wider conditions of capitalist development. For instance, integration into global production networks - and the resultant access to outside resources and markets - is often essential to the regional firms' competitiveness (Scott 1998; Owen-Smith and Powell 2004). Nonetheless, wherever these developments originate from, they must find a regional foothold, become embedded in the regional division of labor and mobilize otherwise unused or under-used regional resources. This eventually requires that regional firms, entrepreneurs and policymakers can be involved and, over time, take the lead in this development (Feldman and Francis 2006). The re-bundling perspective thus addresses those agents with a high centrality in local networks which can become key in embedding and spreading new economic bundles locally. This indicates that re-bundling involves a personal level, aside from the corporate and regional ones. The direction of associated processes depends on the role of leading individuals, such as influential executives, managers, policy makers and their networks. While this paper focuses on the corporate perspective of re-bundling, suggesting that it is important to view regional re-bundling as a bottom-up process which results from various more or less homogenous, individual or collective corporate responses, the epilog demonstrates the importance to also consider the personal level in conceptualizing regional restructuring processes (e.g. Geißel et al. 2003). The potential of certain key individuals to mobilize coherent decision-making and to engage other local, as well as non-local, actors in regional re-bundling may well be a decisive link to successful restructuring and economic revival.

In the first place, the solutions found to a crisis and the decisions made are open-ended. Although they are not independent from existing resources, these do not predetermine the nature of restructuring and adjustment processes. The re-bundling perspective provides an empiricallydriven agenda in understanding these changes and shifts as open-ended development processes. It 
tracks down the corporate decision-making processes and actions, the conflicts associated with them and the hurdles that have to be overcome. The re-bundling perspective thus provides a bottom-up perspective for qualitative studies of crisis-ridden restructuring processes. When emphasizing bundles of resources and the perspective of different re-bundling scenarios in economic and political crises, the goal is to emphasize the need of focusing on the processes of how existing and new resources are mobilized, deployed and redeployed (Bathelt and Boggs 2003).

The possible regional consequences of re-bundling are illustrated in Figure 1, which shows how a regional development path is ruptured by a political or economic crisis (Bathelt and Boggs 2003). This crisis, in turn, sets in motion processes of corporate re-bundling that involve regional and cross-regional resources and can result in new or reconfigured regional development paths, be it associated with regional growth (scenarios (c) and (d)) or with stagnation and decline (scenarios (a) and (b)). It is interesting to note that Martin and Sunley's (2011) review of models in organizational ecology leads to a complementary perspective. Addressing cluster evolution, their work suggests an adaptive-cycle model that distinguishes different cluster trajectories, such as ongoing adaption, mutation, stabilization, re-orientation, failure, or disappearance. ${ }^{2}$ Both conceptions view regional economic processes as bottom-up processes that result from firmspecific individual or collective adjustment processes in production. They require that micro-level (firm-centered) and macro-level (regional) perspectives are connected. The following discussion describes four ideal-type scenarios of regional re-bundling ${ }^{3}$ depending on the specific recombination of resources, production and innovation activities involved (Chapman et al. 2004; Martin 2010):

$* * * * * * * * * * * * * * * * * * * * * * * * * * * * * * * *$

[Insert Figure 1 about here]

$* * * * * * * * * * * * * * * * * * * * * * * * * * * * * * * *$

\footnotetext{
${ }^{2}$ It is debatable, of course, how easily all these diverse trajectories can be subsumed under the umbrella of an evolutionary conceptualization. As opposed to this deductive classification, the re-bundling perspective is inductive and empirically-driven.

${ }^{3}$ This typology was first discussed in Bathelt et al. (2010).
} 
(a) No re-bundling: regional paralysis due to an economic standstill. This case is characterized by massive plant closures and lay-offs leading to longer-term decline. Resources remain unused as unemployment sharply increases and industrial spaces are left empty. Neither existing skill levels nor technological competencies are redeployed. Active re-bundling strategies are not applied, and new economic linkages in production and innovation are not formed. Regional consequences are minimal investments and high unemployment, potentially leading to cumulative shrinking processes.

(b) Un-bundling: out-migration of resources induces relocation of economic activities. This scenario leads to an immediate relocation of key firms to other regions and nations with consequences similar to case (a). Corporate ties lead to a redeployment of some of the resources and competencies but this is associated with geographical shifts, adding to the regional pressure. Persistent regional decline is the result, while the regional resource base shrinks and the mobile labor force leaves the region. Existing production and innovation linkages are minimized and new linkages pass over the region, leaving a deserted, isolated regional economy behind.

(c) Ongoing re-bundling: adaptive resources through continuous restructuring and innovation. This scenario describes a situation where regional firms are prepared to crisis situations as they engage in continuous restructuring and adaptation of existing structures and linkages. They develop a structure that does not depend on specific production or technological settings but builds on the capacity to flexibly adjust products and services based needs on intensive producer-user linkages and ongoing search for new markets. The crisis still impacts the regional resource base but firms are able to benefit from prior successes, reducing the regional effect of the crisis. The likely trajectory draws on cumulative development patterns possibly leading to slow but steady recovery and avoiding sudden economic decline.

(d) Radical re-bundling: attraction of new resources leads to shift in production. The last case is the most optimistic scenario in terms of the mobilization of external resources and the engagement of new firms in restructuring and modernization. It refers to a situation where multinational firms or other external organizations recognize the value of existing resources and decide to invest into a modernization and re-deployment of these resources, leading, for instance, to acquisition and investment projects. This may result in a shift of the regional industry core toward new production structures leading to a reconfiguration of economic 
linkages. This could be conceptualized as a regional branching process (Boschma and Frenken 2011), in which new industrial developments spin off into related areas, but linkages to existing competencies might also be weak. Radical re-bundling processes can go along with a strong integration into cross-regional and international value chains.

Similar to the cyclical model of Martin and Sunley (2011), shifts from one stage of rebundling to another one can occur, for instance from case (a) - if persistent - to case (b), or from case (c) - if successful - to case (d), or by triggering external investments from case (a) to case (d). In this paper, the conception of economic and political ruptures and re-bundling is used to analyze the restructuring processes of the chemical industry in the Bitterfeld-Wolfen region - one of the largest European agglomerations of chemical production in the post-World War II period. After Reunification, prior economic and ecological exploitation processes required that many activities had to be terminated or drastically restructured, leading to massive un-bundling processes. At the same time, federal and provincial funds were activated to support re-bundling processes in the region. While entrepreneurship is seen as critical factor in developing resilient regional economies (Malecki 2009), the analysis that follows pays attention to the ability of existing firms to re-bundle their resources and competencies during times of economic upheaval, and to the prospects of mobilizing external firms and resources to engage in restructuring the regional development path.

Before turning to the results of this research, the next section discusses the methodology applied in the empirical study.

\section{Methodology}

The research presented in this paper began in 1995 in the context of a wider explorative study of the restructuring processes and changing social and spatial divisions of labor in the German chemical industry (Bathelt 1995). Between 1995 and 2006, five research trips - with a length of 3 to 14 days each - were organized to conduct interviews with representatives of chemical and other firms, politicians, planners, industry experts and critical observers about the industry's development and transformation in the Bitterfeld-Wolfen region. This project was based on a qualitative research design and involved semi-structured interviews and repeated site visits (some firms and organizations were visited three to five times over the entire time period). 
The main goal was to explore and document the corporate restructuring processes and associated re-bundling of resources in the chemical industry, as well as in related supplier and service industries. To study re-bundling activities over such a long time period provided unique opportunities to collect information about initial actions and experiments (e.g. start-ups) and later revisions of strategies (e.g. management buy-outs). While this research did not involve production activities that were closed down in the early 1990s, many of the managers and experts interviewed were able to provide detailed information about early developments, which they had witnessed. In addition, there was substantial media coverage about the events and their respective backgrounds. These early processes are referred to in this paper insofar as they were relevant for the re-bundling processes that took place later on.

To distinguish short-term from more durable forms of re-bundling and to explore how corporate restructuring processes and investments produced specific industrial structures (for instance, in terms of regional producer-user linkages) that led to new sets of actions later on, a diachronic approach was applied, similar to the methodology described by Barley and Tolbert (1997). When investigating regional re-bundling processes in a bottom-up fashion by studying corporate restructuring processes, one has to keep in mind that firms do not deploy the same strategies and recombine resource in identical ways, but choose different paths and strategies. To capture this multiplicity of responses to the transformation pressures after Reunification, firms were in the first stage of the analysis classified into types of firms with similar re-bundling potential and similar access to resources. This typology was based on three variables: ownership structure, access to external resources and position in the value chain. According to these variables, seven types of firms (including two subtypes) were identified (Table 1). Of these, types 1 through 4 focus on the core of the chemical industry, while types 5 and 6 encompass the supplier and service sector as well as the related environmental activities. ${ }^{4}$

[Insert Table 1 about here]

\footnotetext{
${ }^{4}$ Type 6 of independent chemical service providers is the largest and most heterogeneous group of firms. Although it would have been possible to further split up this group, this was not done as the focus of this paper was directed toward the core of the region's chemical industry. Developments of the type 5 and 6 firms were analyzed with respect to the re-bundling potential of type 1 through 4 firms.
} 
$* * * * * * * * * * * * * * * * * * * * * * * * * * * * * * *$

In the next stage of the analysis, the restructuring and re-bundling activities of the firms of each type were analyzed separately. The main points of the inquiry focused on the availability of finance for new investments and modernization activities in production, the development of longterm business strategies, access to advanced technical and innovative capabilities and the local involvement therein, linkages with other local/regional firms in production and associated knowledge flows, learning processes and growth triggers, and so on. In the interviews conducted, the gal was to assess how changes in the economic and political conditions affected the production settings, supplier-customer relations and innovation processes that then led to initial corporate structures in production and innovation (Barley and Tolbert 1997; Orlikowsky 2000). Since these experiences and changes in the institutional settings induced further re-bundling activities later on, this research involved series of interviews over time with some of the major chemical firms, as well as industry observers, planners and politicians. At the end of this stage of the analysis, the firm-specific adjustment processes and investment decisions were aggregated in a stepwise manner into re-bundling responses by firm type.

The final stage of the analysis was to aggregate firm responses to the economic and political crisis further into a regional perspective to be able to evaluate the overall regional restructuring process in terms of the different re-bundling scenarios discussed above. Due to the nature of this diachronic analysis, interviews were conducted with a similar group of industry experts, managers and politicians over an extended time period and many conversations emphasized the roles of local/regional leaders that supported and launched regional economic and political initiatives and programs. Over the course of the research project, it became clear that a group of well-respected, influential leaders with broad personal networks played a key role in the economic restructuring processes in the region, constantly mobilizing and reassuring broad support. Although these people were not at the center of this research, their decisive roles in the re-bundling processes of the Bitterfeld-Wolfen chemical industry are emphasized in an epilog to this paper.

The firms to be interviewed were chosen from regional business directories (Unicepta Abels \& Partner 2002; 2005). Based on media reports about the region, yearly revised business directories and information from explorative field trips, a list of nearly all new, minor and major firms/investments in the Bitterfeld-Wolfen chemical industry and its supplier and service sector was developed and constantly updated. To conduct interviews, all firms in the chemical industry 
and all larger supplier and service firms were approached. In addition, further service and supplier firms were randomly selected, stratified by sector, size and location. The firms were asked to participate in this study by agreeing to an interview and a guided tour through their production facilities. Through this process, a total of 63 chemical firms and their suppliers and service providers were interviewed (Table 1), adding up to over 70 interviews. Of these firms, 24 (38\%) were interviewed in 1999, 34 (54\%) in 2002 and most of the remainder in $2006 .{ }^{5}$ Additionally, 16 explorative interviews were conducted between 1995 and 2006 with economic development offices, local politicians, industry observers, retired managers and firms from unrelated sectors. Based on triangulation of the firm interviews with information received from media reports, regional industry experts and planners, this research provides a sound basis to carefully draw conclusions about the wider prospects of economic growth and development in the Bitterfeld-Wolfen region. Overall, it can be assumed that this sample of firms provides an overview of the important restructuring and re-bundling activities in the Bitterfeld-Wolfen chemical industry and related supplier and service industries.

The questions asked focused on the transition of chemical production after Reunification. In the beginning, questions were asked about changes in ownership, strategic focus and production program since Reunification, and the reasons for choices made in investment targets and strategy development. This set of questions aimed to explore the access to and nature of resources that became available in the restructuring period. A second set of questions focused on the supplies needed, the nature of supplier relations, potential problems with suppliers and their geographical distribution, as well as the importance of regional suppliers. Next, a similar set of questions were asked about customer relations, before aspects regarding research and development, knowledge acquisition and innovation processes were raised in the final set of questions. The questions intended to explore the potential for the development of regional networks and associated growth triggers, as well as learning processes through ongoing supplier-producer-user linkages. The overall goal of these questions was to document the nature of re-bundling activities and draw conclusions about the firms' contributions to regional re-bundling.

The interviews took on average 45 to 90 minutes, followed by a 60 -minute field tour through the production facilities. As most of this research occurred in a period of substantial

\footnotetext{
${ }^{5}$ The overall rejection rate of less than $20 \%$ was acceptable compared to other studies.
} 
restructuring, mass lay-offs and high uncertainties about future developments, the decision was made early on not to tape the conversations. Instead, notes were taken during the interviews and extensive protocols written up for each interview - usually on the day of the interview. The protocols formed the basis for the empirical analysis presented in the following sections. Instead of citing from the interviews, the main findings are illustrated through typical cases. In the empirical investigation below, these cases, their activities and strategies are described in more detail.

Before turning to the results of the empirical analysis, the next section provides an overview of the historical transformation of the region and the practices of economic and ecological exploitation in the post-World War II period which required drastic restructuring after Reunification.

\section{Context: Post-World War II Practices of Economic Exploitation in Bitterfeld-Wolfen ${ }^{6}$}

The conditions for major growth of the chemical industry in the Bitterfeld-Wolfen region developed relatively late during the 1920s and 1930s when larger chemical operations were established as branches of West German firms (Chemie AG Bitterfeld-Wolfen 1993; Dühr 1998). At that time, other chemical industry regions in West Germany had already developed integrated production capacities. Initial production began in the late 1800 s closely related to the brown coal mines in the region. These served as a rich energy basis for chemical production. First investments were made by the Chemische Fabrik Griesheim, a subsidiary of the Allgemeine Elektrizitätsgesellschaft (AEG), and the Actien-Gesellschaft für Anilin-Fabrikation (Agfa). These activities included the production of basic chemical products, such as chlorine, and photochemicals.

After World War II, the chemical firms were occupied by Soviet troops and later reorganized into so-called Kombinate, characterized by rigid hierarchies with a high degree of vertical integration, yet a limited variety of products (Topel 1984; Haase 1984; Schwartau 1980; 1989). The intensification of chemical production since the 1960s led to dramatic environmental

\footnotetext{
${ }^{6}$ The historical context is a summary of earlier analyses presented in Bathelt $(1995 ; 2009)$.
} 
pollution, especially in terms of air quality, soils and ground water. Due to high-pollution brown coal power plants and practices of depositing toxic waste materials, the region was notoriously known as being one of the dirtiest spots on the planet (Bathelt 1995). At the same time, a lack of investment led to an industry structure that suffered from low productivity levels and the need for massive modernization. Already dated technologies, which could be found, for example, in the Bitterfeld production facilities for nitric acid or the carbide ovens in Schkopau, were exploited without fundamental modernization. Through these practices, the already problematic environmental situation got worse without solving economic problems (Schwartau 1987; Spiegel 1990; Chemie AG Bitterfeld-Wolfen 1993; Dühr 1998; Mitteldeutscher Rundfunk Online 2010). ${ }^{7}$ The environmental conditions under which people had to live and work were described as inhumane in media reports and TV documentaries (Rupieper et al. 2005). Outdated technologies were hazardous and led to chemical accidents, which were kept quiet.

Observers, such as Faupel et al. (2001), suggested that a substantial part of the chemical production processes and facilities had already existed before World War II and were completely outdated at the time of Reunification with high production costs, over-employment and a lack of specialty chemicals and high-quality consumer products. ${ }^{8}$ Related to these deficits and along with the lack of market/marketing experiences and the loss of traditional export markets in Eastern Europe, most chemical firms were not able to gain international competitiveness and had to undergo radical restructuring (Schmidt 1997). Plants with obsolete and environmentally harmful production were shut down shortly after Reunification and most other plants had to reduce production and employment to a minimum. In the Bitterfeld and Wolfen economy, this had disastrous consequences as most of the jobs were lost. Of the originally over 130,000 jobs that

${ }^{7}$ Soil analyses, for instance, revealed heavy concentrations of toxic substances, such as chlorobenzene, cadmium and other heavy metals in the flood plains of near-by rivers (Brückner et al. 1993; Borsdorf et al. 1993; Petelet-Giraud et al. 2007).

${ }^{8}$ Due to the focus of this research on post-Reunification restructuring processes, data about the details of the prior production structure, in both East and West Germany, are not analyzed. Other studies that present related research are cited. 
existed in the chemical industry in the regions of Sachsen and Sachsen-Anhalt, only 16,500 were left by 2008 (Verband der Chemischen Industrie 2009: 58f.). ${ }^{9}$

As it was clear that the restructuring and privatization processes required a concerted effort and strong guidance, a new federal trust agency - the so-called Treuhandanstalt - was established in 1990 to oversee and guide these processes. Some of the key goals of this agency were to preserve existing industrial structures instead of splitting them up. In other words, the Treuhandanstalt aimed to sell chemical industry Kombinate to potential investors in the form of large complex units rather than as individual plants and subunits. This policy was, however, not very successful and was replaced by a new one that prioritized partial privatization (Bundesanstalt für vereinigungsbedingte Sonderaufgaben 1997; Dühr 1998; Hertle 2001). This was a shift in policy that was heavily criticized because it did not support East German plants in restructuring and adjusting to market conditions to become globally competitive. The privatization process of the Treuhandanstalt assumed that the acquisition of existing operations would automatically lead to such competitive structures. In this period, however, many media reports indicated that plants and jobs could have been saved through a different, more careful, long-term investment policy, instead of splitting Kombinate up and creating truncated production networks (Albach 1993). This generated hurdles, for instance, in stimulating regional multiplier and interactive learning processes.

Many activities were terminated instead of being modernized as the Treuhandanstalt was not able to find investors. This initiated massive shrinking and un-bundling processes caused by resources leaving the region. The decision to split up the Kombinate and sell the divisions separately was heavily criticized in the public discourse. As a result of these practices, those parts of the former Kombinate with specialized competencies were quickly sold while other operations were left in isolation. The case of the former production of photo-chemicals and film-packs in Wolfen was highly disputed as attempts at providing a longer-term perspective for survival failed (Frankfurter Rundschau 1994; Chemie-Produktion 1996; Dühr 1998). Reports in the media frequently argued that a different Treuhandanstalt policy approach could have saved broader production complexes if some of the market leaders in the industry had become involved, made

${ }^{9}$ One has to exercise care, though, in interpreting this decrease in employment, as the industry was characterized by over-employment and included operations not related to chemical production. 
acquisitions and modernized such activities later on. ${ }^{10}$ Important types of corporate re-bundling processes that took place under these conditions are described in the next section.

\section{Empirical Analysis: Corporate Re-bundling in Bitterfeld-Wolfen after Reunification}

Of all chemical production regions in East Germany, the economic and environmental problems that had developed in Bitterfeld and Wolfen were especially severe, and it proved to be challenging to secure chemical production activities in the region. Bitterfeld was characterized by a fragmented, diversified production structure of chemical products, referred to as the "pharmacy of the German Democratic Republic" in former times. Even after initial un-bundling and rebundling processes changed the regional economy, Becker (1995) described the region as a "patchwork blanket" with production activities that were hardly linked with one another. Since potential investors were not found that could have modernized large segments of the former Kombinate, the region's future seemed to be at stake. In 2001, the area of the two former Kombinate was transformed into a privately-run chemical industry park, i.e. the P-D ChemiePark Bitterfeld Wolfen GmbH that opened up the formerly closed and protected territory. The PreissDaimler group managed the industry park and provided essential services to the local chemical firms. The park was $12.4 \mathrm{~km}^{2}$ in size and hosted some 350 firms (P-D ChemiePark Bitterfeld Wolfen GmbH 2002; http://www.chemiepark.de, date accessed March 13, 2007).

The re-bundling processes of the region's chemical industry would not have been possible without the preservation and reinvigoration of minimal material linkages. Structurally, such linkages were never key attributes in the fragmented chemical production landscape, but the local chlorine production had always been a defining anchor. It proved to be very difficult to maintain production linkages or establish new ones as the chemical activities were much diversified with little overlap and few value-chain linkages. The massive closures made it even more difficult to

${ }^{10}$ While such processes were commonly criticized in my interviews during the 1990s, managers, investors and observers were less interested to talk about cases of failure in the mid 2000s. One manager, who had worked in Bitterfeld already before Reunification, emphasized that people in the industry were tired of looking back. They preferred to look forward, focus on the challenges ahead and work on solving them. 
establish any kind of material linkages. After several years of ambiguity and different plans, ECI Electro-Chemie Ibbenbühren from West Germany finally acquired the local chlorine production activities in 1997. After its modernization, the plant became the core player and supplier of a chemical production cycle with about half a dozen of other local chemical firms. Among the products involved in this cycle are hydrochloric acid, technical gases, silicon tetrachloride and related products for the production of quartz glass (Derlien et al. 1999; Schmid 2000). Despite all restructuring activities and investments, employment levels in the regional chemical industry have remained lower than expected. As estimated by Bathelt (2009) based on a wide variety of sources and media reports, investments in the region's chemical industry park totaled of about $€ 2.7$ billion. In the end, about 50 chemical firms and 300 other firms, only partially related to chemical production, were located in the region only employing an estimated 3,000 and 6,500 people, respectively (Bathelt et al. 2004).

Under these conditions, corporate re-bundling processes were slow, differed from case to case (Land 2006), and hardly exhibited "cluster qualities" (Rosenfeld et al. 2007). According to ownership structure, access to external resources and position in the value chain, seven types of firms (including two sub-types) were identified in the Bitterfeld-Wolfen chemical and chemical supplier industry. The firm types differed with respect to their potential path of re-bundling and the use of existing or new resources (Table 2). This contributed to ongoing segmentation tendencies (Schmidt 1997; Kollmorgen 2005). As subsequently shown, the different types represent different intensities of re-bundling that will not necessarily generate strong regional networks and economic growth in the future. This is analyzed next, before attempting to aggregate restructuring activities into a broader picture of regional re-bundling in the final section of the paper.

[Insert Table 2 about here]

\section{Type 1a: Acquisitions/investments by West German chemical multinationals (5 firms)}

Firms of this type are Brownfield or Greenfield investments that benefited from the inflow of fresh capital from outside, enabling more radical re-bundling processes. Although this firm type consisted only of 5 (of 63) sample firms, these were very important. They were among the 
largest facilities in the region in terms of employment and brought in external competencies that did not exist before. The firms accounted for approximately $44 \%$ of the chemical labor force in the region (although there are no official statistics available). In most cases, West German multinationals acquired regional plants and integrated the respective activities into their national and international corporate networks. The rationale for such acquisitions was usually related to pre-existing specializations in production, and the goal was to complement existing production or maintain traditional cores of production. Access to investment capital, new technologies and wider markets was usually not a problem for the acquired plants, since they benefited from established international production and distribution networks through their parent organizations.

Although the new operations were characterized by state-of-the-art technologies, the degree of integration into the regional economy was limited. On the one hand, these were often production or assembly plants with hardly any research, management and even sales functions; products typically fed into corporate material cycles and were shipped to and handled by distribution centers in West Germany (for a similar example in northeast England, see Kirchner 2000); employment levels were relatively low; and, as a consequence, decisions about research directions, new suppliers and changes in production programs were made elsewhere. On the other hand, the degree of regional embeddedness and the contribution to regional networks remained very limited due to the dominance of corporate linkages (see, also, Land 2006).

As described by Bathelt (2009), the most important investment in the region's chemical industry was that of Bayer to establish facilities in the region (Oelke 1998). The firm that had historical ties in the region always emphasized that this was a political decision, not one made for market reasons or cost considerations alone. The decision was strongly pushed by the federal government and former Chancellor Helmut Kohl. In total, Bayer set up four specialized plants over the years in the areas of pharmaceutical production, methylcellulose, resins and ion exchange. These plants operated independently from one another without internal material flows and not much interaction. Without Reunification, these projects would have likely been realized close to Bayer's headquarter location in Leverkusen. All four investments appeared to have been successful and profitable in Bitterfeld, as the firm was able to benefit from lower labor costs, subsidies through the economic support program "Aufbau Ost", and the possibility of longer production runs due to opening clauses in the collective agreements between unions and employer associations. Overall, Bayer created about 500 new jobs in the Bitterfeld region prior to 2000 (Kaiser; Becker 1995). Despite this, the firm was only loosely embedded in the regional 
economy: material linkages with other local firms - be it within or outside the chemical industry - were negligible; research activities were not carried out locally; and the distribution of products to the markets was organized by the headquarter location in Leverkusen. Despite this, the firm's location decision was of great significance for the region. It was presented in the media as an anchor investment, portraying the region in a positive light as a place that was leaving its past legacy behind. However, Bayer always remained somewhat separate and independent from the region's chemical industry development, which was, for instance, expressed in the firm's rejection to locate inside the territory of the former Kombinat. The firm rather chose to locate outside this territory to avoid potentially problematic in-situ pollution and to remain independent from specific regulations in the area of the former Kombinat. ${ }^{11}$

Firms of this type made decisions about supplier and customer linkages and distribution channels through pre-existing corporate hierarchies located outside the region. Overall, the region lost most of its research and development facilities through these acquisitions (Dühr 1998). None of the firms were able to add enough new jobs to the regional economy to offset the jobs which were cut earlier. Additionally, envisioned expansion and investment plans were sometimes called back later, slowing down the development of the region. When, for instance, Bayer's industrial chemicals division became independent in 2005 related to global reorganization of all business units, this had direct consequences on future plans (Bathelt 2009). Further expansion was now unlikely and, therefore, the decision was made scale down the firm's territory by establishing a small chemical industry park to attract other investments, placing the firm in direct competition with the Preiss-Daimler group. Although the labor force of Bayer grew to almost 800 people, it became clear that further new investments would be unlikely in the future (http://www.bitterfeld.bayer.de, date accessed March 12, 2007).

In another case of this type, Heraeus from Hanau revised its original growth when quartz glass production stalled in the early 2000 s due to a decline of markets that were tied to the U.S. telecommunications industry. The consequence was similar to that of other firms. Further investment plans were cancelled and employment was reduced to about 450 as suggested in the media (Frankfurter Rundschau 2001). Overall, it turned out that additional major investments in the chemical industry were unlikely and that corporate re-bundling had come to a standstill. This

\footnotetext{
${ }^{11}$ Similarly, Guardian Flachglas also established production outside the former Kombinat in Wolfen.
} 
had further consequences for the service and support facilities in the region. It turned out that projects, such as a new modern sewage plant, had been scheduled too optimistically related to unrealistic growth projections in the initial planning processes (Bathelt 2009). ${ }^{12}$

In sum, firms of this type were crucially important for regional development, signaling that it was possible to attract investments of industrial leaders from West Germany. They became anchor investments that created optimistic views about future prospects in the region and stimulated hope for further growth. Overall, however, there were too few investments of this type and those that existed created only limited producer-user linkages. They did not have a broad regional impact and did not initiate fundamental re-bundling processes.

\section{Type 1b: Acquisitions by foreign chemical multinationals (9 firms)}

Operations acquired and reconstructed by foreign multinational firms made slightly greater regional commitments in terms of material linkages, although they were also bound to strong corporate loyalties (Günther and Gebhardt 2005). Operations of this type include firms, such as Guardian Flachglas, Akzo Nobel and Ausimont. They established more substantial local supplier linkages when materials could not be supplied through their corporate networks. Overall, the number of foreign multinational chemical firms that invested in the region was limited, however, with only 9 firms included in this study. Their scale of investments was usually smaller than that of type 1a firms, employing between 50 and 100 people. The facilities involved quickly gained international market access through corporate distribution channels. The firms typically established branches in Bitterfeld-Wolfen between 1994 and 1998. Despite their limited size, they still had an important regional impact on the labor market and accounted for about $22 \%$ of all jobs in the chemical industry.

Firms of this type usually focused on few specialized production activities that were originally not part of their corporate portfolio typically related to a regional producer with some prior competencies in this area. One example is a U.S. firm that acquired two facilities related to

\footnotetext{
12 Another example is an engineering firm specialized in chemical plant layout that was originally founded in 1990 as a joint venture of Preussag AG and the Chemie AG Bitterfeld. Since the firm was not as successful as projected, it had to reduce employment from 80 to 25 people and was sold in 2000 . This was largely due to the slow growth of the regional chemical industry and fierce competition.
} 
the production of industrial catalysts and molecular filters and invested into fundamental modernization. The employment effect of this investment, however, remained limited with about 70 employees in the mid 2000s. Another firm with a production focus on plastics recycling developed its original competencies through linkages with former production activities in the region. The firm was re-established collaboratively with a Dutch partner providing international market access from the very beginning and enabling strong capital flows and investments. The firm was successful and grew to over 40 employees after 2000. All of these facilities remained strongly committed to pre-existing international corporate networks and had little say with respect to corporate strategy, innovation and marketing. Their regional customer base was small, yet most firms had at least some linkages.

Few firms integrated their activities into a regional chemical cycle. These firms reduced international supplier relationships to some degree and developed stronger regional linkages. The largest and most well-known firm of this type is Guardian Flachglas. The firm was established in 1997 and grew to a size of 360 employees within only five years. Like other foreign branches, Guardian drew upon a global customer base, yet was also related to competencies that already existed in the region.

Although German and foreign multinationals received the largest share of the overall financial subsidies, available for the establishment and modernization of chemical operations in the region, their contribution to regional employment in terms of the absolute number of jobs remained limited. From media publications, it can be estimated that type $1 \mathrm{a}$ and type $1 \mathrm{~b}$ firms together created about 1,950 of 3,000 chemical industry jobs in the region (Bathelt et al. 2004).

Despite the importance of type $1 \mathrm{~b}$ investments in providing access to multinational distribution networks and new technologies and in creating new production linkages in the region, their effects on regional re-bundling remained limited. These facilities were too small to have a broad regional impact and their technology focus was quite heterogeneous, directed toward different specialized branches of the industry.

\section{Type 2: Chemical management buy-ins or buy-outs (11 firms)}

Management buy-ins or buy-outs are interesting because they are usually based on regional capital and pre-existing competencies. In Bitterfeld-Wolfen, such activities primarily involved research divisions or specialized production facilities of the former Kombinate. Investment 
activities were limited though because they depended on personal capital or savings of the entrepreneurs and their contact networks. Re-bundling processes initiated through these firms were more incremental in nature than those of type $1 \mathrm{a}$ and type $1 \mathrm{~b}$ firms, and they depended on existing competencies.

Comparatively few management buy-ins or buy-outs occurred in the Bitterfeld-Wolfen region, although 11 such firms were identified in this research. They occurred in relatively knowledge-intensive segments of the former Kombinate and were launched with substantial involvement of and support from the labor force. Overall, it seemed that management buy-outs with little know-how inflows and capital inputs from West German partners tended to be less successful (and sometimes failed after a decade or less), compared to those with strong involvement of West German partners. In the case of the former Filmfabrik Wolfen, only parts of the related production activities were able to survive. A few notable, yet relatively slow-growing or stagnant management buy-outs were among these firms. One firm in the area of organic chemicals had specialized in small-scale syntheses of chemicals according to customer specification. The firm was established in 1997 by three people who continued to work in the old facilities. The operations remained small, however, with a total of less than 10 employees, even though the new firm was successful in acquiring a stable customer base with international partners in the U.S., Switzerland, Belgium and Japan. The firm was also able to secure a significant regional market volume.

Another management buy-out was CBW Chemie GmbH Bitterfeld-Wolfen (Emr 2002). ${ }^{13}$ Along with the buy-out process, the firm shifted its focus from producing standardized chemicals toward custom-tailored syntheses of organic intermediates and dyestuffs. This required substantial investments into multi-purpose machinery (about $€ 23$ million). The firm seemed successful with its strategy, even though it still used somewhat older technologies. In terms of jobs, it developed continuously and had about 170 employees in 2009 (although substantially smaller than the former Kombinat operations). This was a significant contribution to the regional economy.

According to the interviews conducted, a number of firms of this type were struggling to survive after only a few years time. One stream of production of fine chemicals that had a long

\footnotetext{
${ }^{13}$ The firm was established in 1997 by Max Bräutigam, a former Treuhandanstalt manager.
} 
tradition was originally established in the early 20 th century. The management buy-out that occurred after the Reunification was possible because the entrepreneurs were able to mobilize additional external finance through former partners from West Germany. Starting with about 25 people in the mid 1990s, employment decreased to about 10 people within a decade. Another management buy-out - one of the largest in the region - started off in 1993 with 570 employees. The firm was transformed from a research and development division of the former Kombinat into a firm with a broad maintenance, repair and process engineering competence. The six founders primarily concentrated their business on the regional chemical industry (that accounted for more than half of their sales) with the expectation that this industry would recover and grow in the future. As this expectation proved wrong, as competition grew stronger, and as branches of multinational chemical firms tended to use their established corporate suppliers, the management buy-out had to downsize substantially over time, ran into financial problems and eventually shut down operations. Overall, few firms were able to flourish based on ongoing re-bundling activities that were related to pre-existing competencies. This was due to the fact that most firms had lost their former transaction partners and networks of suppliers and customers, many of which had been shut down or become embedded in other corporate contexts. This resulted in truncated networks (Albach 1993; Bühler 1999).

\section{Type 3: Innovative chemical start-ups (7 firms)}

From a regional planning perspective, this is probably the most interesting type of firms because their establishment rests on innovative ideas. These firms typically involve a substantial amount of regional resources and personnel (for instance, founders who studied in the region), thus leading to ventures with a stronger regional commitment. Firms of this type, however, have to establish market presence and legitimacy first to be able to survive (Hannan and Freeman 1984).

Few new innovative start-ups were launched during the restructuring process in BitterfeldWolfen. In the survey, 7 such businesses were identified (of 63 firms overall) - more though than originally anticipated. Most of these firms were started up around 2000. The phenomenon of the "new entrepreneur" described by Thomas $(2003$; 2005), who operates at the economic margin, was apparently not very pronounced in the chemical industry. 
In the former Filmfabrik Wolfen, firms of this type were located in the facilities of a technology and incubator center founded in 1992, i.e. the TGZ Technologie- und Gründerzentrum Bitterfeld-Wolfen GmbH. Under the management of Manfred Kressin, the TGZ established a total of $9,000 \mathrm{~m}^{2}$ of office and laboratory space targeted towards new start-up firms with linkages to chemical production and the regional industry structure (http://www.tgz-chemie.de, date accessed March 12, 2007). Firms in the TGZ focused on small-batch production and customerspecific solutions in areas, such as biotechnology and environmental technology. Although these firms developed only sparse connections with the traditional production core, they proved to be resilient. They had the status of niche operations in small, specialized markets with less than 10 employees. Aside from developing new products and conducting contract research, two of the firms also offered specialized, small-scale, customized chemical syntheses to their customers. The latter activities, according to one founder, helped to finance ongoing innovation processes.

Most of these firms already had interregional and international linkages prior to their establishments related to personal networks. These were later mobilized and transformed into customer contracts. Although the firms seemed to have some future growth potential, they were originally struggling to survive. During the 2000 s, they had seemingly stabilized, yet employment remained low. All firms of this type had a widely distributed customer base with national and international linkages. One contract research firm and producer of customer-specified pharmaceutical agents was founded in 1999 by three former chemistry students from the University of Leipzig, where they had received their Ph.D. degrees. Based on market potential studies, they decided to start their own business. Although successful in gaining attention from large multinational pharmaceutical firms, their growth was gradual and seemed to be a tedious process. The founders were lucky as they were able to benefit from pre-existing personal networks with former fellow students and friends. In contrast, regional linkages were almost nonexistent and not important.

In addition to these start-ups, a number of small to medium-sized firms were established in the area of organic and fine chemicals based on favorable opportunities (i.e. existing low-cost facilities) and competencies found in the region. The original goal to develop regional market linkages was quickly given up and the firms instead sought interregional and international markets. They developed steadily but did not grow into larger operations. The fastest growing firms of this type had international market linkages and customers beyond the chemical industry. One such firm that specialized in customized organic and fine chemical production focused on 
the international electronics industry, employing over 50 people. This firm, however, was an exception.

Overall, this type of firms was unable to stimulate radical re-bundling activities due to a lack of market legitimacy in the sense of Hannan and Freeman (1984). They did not have enough support to find quick market access to draw additional resources and capital into the BitterfeldWolfen region.

\section{Type 4: Investments of small and medium-sized West German chemical firms (4 firms)}

Investments of this type were able to mobilize substantial imports of capital from outside and stimulate the transfer of key competencies in marketing and management to the region. Although these investments were substantially smaller than those of type $1 \mathrm{a}$ and type $1 \mathrm{~b}$ firms, the engagement of small- and medium-sized firms went along with a distinct regional commitment. This was likely related to the fact that these firms were not integrated into broad corporate decision-making hierarchies. Investments of small- and medium-sized firms from West Germany tended to have the strongest regional impact, relative to the size of their investments. They had a strong commitment to involve the local labor market and make use of regional supplier networks, if possible. However, the number of such investments remained relatively low, with only 4 of the 63 firms in the sample.

One producer of basic chemicals established in the region in 1997 was very successful in acquiring regional customers and expanding further. The medium-sized chemical firm from West Germany was able to double its employment within ten years. The strategy was to address regional chemical firms and establish close customer contacts. As a consequence, the firm gained about 60 regional customers and became a supplier for half a dozen firms in Bitterfeld (Derlien et al. 1999). Another producer of pharmaceutical agents and intermediaries, originally headquartered in the Ruhr area, viewed an engagement in Bitterfeld as an opportunity to widen its market reach and to expand, which had not been possible at its West German site. The firm that started in Bitterfeld in 1995 had already about 20 employees in 1999 and continued to shift production functions and competencies to the new location. The local management, headed by the owner's son, was committed to use regional suppliers as much as possible (15-20\% of all inputs), while $80 \%$ of production was exported to other countries. The firm clearly benefited from being 
part of a supra-regional network of about 50 small and medium-sized firms that jointly distributed their products worldwide.

Overall, the firms of this type benefited from ongoing incremental and somewhat more radical re-bundling based on their ability to mobilize external capital and draw on wider preexisting markets.

\section{Type 5: Environmental clean-up and consulting firms (6 firms)}

Activities in the field of environmental clean-up and protection developed rapidly since the early 1990s as a consequence of the disastrous environmental situation and toxic waste problems that required immediate action. Firms of this type that were established in Bitterfeld-Wolfen often had a consulting focus and remained limited in size. During this research, 6 firms of this type (of 63 firms) were interviewed. Some of the firms had primarily been established in the region to benefit from federal government programs available for clean-up. Environmental services and consultants, which grew rapidly in number after Reunification, often left or downsized when much of the clean-up was completed and fewer subsidies were available. These clean-up activities did not trigger innovation.

Innovative environmental activities and start-ups with a close connection to existing chemical branches remained limited. Firms of this type were usually not involved in networks or cooperations with other regional firms. One exception was a recycling facility that developed competencies in the recycling of certain types of plastics in the region. Another firm that was founded in 1999 developed new products in the area of wastewater treatment. The firm was able to establish a niche market for its products primarily in southern Germany. Overall, however, these firms did not experience high growth and remained small with typically less than 10 employees.

Type 5 firms did not contribute actively to economic re-bundling, yet they were key in what could be referred to as "environmental re-bundling". They set the scene for the attraction of capital and investments from outside the region by generating more favorable environmental conditions as a precondition for other re-bundling activities. 


\section{Type 6: Independent chemical service providers (21 firms)}

Firms of this type were established after Reunification to provide largely standardized services to the chemical industry, and sometimes also for other industries. This type of firms consisted of heterogeneous activities, ranging from few larger establishments which had been acquired by German multinational firms to a number of management buy-outs and new start-ups in less investment-intensive business segments. ${ }^{14}$ They collectively formed a relatively stable segment of the local economy and supported chemical manufacturing, although direct linkages and knowledge exchanges with chemical customers were limited. Even though these firms experienced a growing demand in the post-Reunification period, most remained small in terms of employment and did not have a large impact on the labor market. Some were primarily traders and distributors with a standardized product offering and a competence focused on chemical services.

One firm that specialized in selling protective clothing and fire protection equipment for chemical production was established in Wolfen in 1991. The founders had worked in the regional chemical industry before and were laid off early on. Although the firm first specialized in providing services for regional firms, its market expanded quickly to include other German chemical regions as the owners realized that Bitterfeld-Wolfen would remain much smaller than before. As a consequence, subsidiaries were established in other East German regions, and the number of regional employees increased from 2 to almost 20 within a decade. Although the firm had a larger number of regional customers - among these some of the largest regional firms of type $1 \mathrm{a}$ and type $1 \mathrm{~b}$ - most typically ordered small quantities. Producer-user interactions did not have an innovation focus but were primarily sales relationships.

Other specialized service firms that moved to Bitterfeld-Wolfen had already existed before Reunification in West Germany. With the restructuring processes, these firms established branches in the region to establish a market presence. One such producer of specific containers and barrels formed a branch in Bitterfeld in 1997 that grew quickly within three years to employ about 100 people. Their local customer base, however, was smaller than expected and close

\footnotetext{
${ }^{14}$ Since the focus of this paper is directed toward the core of chemical production, these firms were not classified further.
} 
customer relations with near-by users remained limited. The firm had to address wider interregional markets to continue to grow.

Service providers, which focused primarily on the regional chemical industry, often stagnated or shrunk over time. They were certainly not at the core of re-bundling activities but generated favorable conditions for such processes to occur. The firms often offered standardized chemical or related goods and services to chemical manufacturers. One producer of specific glass equipment for laboratory use was established by former Kombinat employees to produce customized solutions for regional chemical firms with which personal relations had already existed before Reunification. The firm subsequently failed to develop markets outside the Bitterfeld-Wolfen region and, as a consequence, shrank to only few employees in the early 2000s. Interestingly, there seemed to be an over-capacity of producers or traders that offered metal tubes, basins, pipelines and related maintenance services in the region. At least 4 firms in the sample offered such services for chemical production processes. ${ }^{15}$ In the mid $2000 \mathrm{~s}$, they had between 50 and 100 employees primarily serving a regional customer basis. Several firms had originally viewed the growth of the chemical industry too optimistically. Competition became even stronger due to the practices of multinational chemical branches to bring in their long-term corporate service providers, instead of regional businesses. The consequence was that several firms suffered from low sales and stagnation. They had to downsize or approach wider German markets. One of these firms was originally established as a management buy-out from one of the research divisions of the former Kombinat. Although the firm was initially viewed as a prototype of successful business development, it ran into financial problems and was shut down in the mid 2000s.

In the area of machinery production and other supplies, firms that originally had some business in the chemical industry increasingly moved into other markets, leaving hardly any regional customer linkages or supplier relationships in the region. They removed ties from the

15 The two largest ones had 200 and 1,200 employees in 1999. They were both acquired by major West German firms, and were integrated into their corporate networks. Already then, they had undergone substantial changes and downsized their activities as business declined. This decline continued throughout the 2000's and went along with international acquisition processes and wider consolidation in the industry. 
former core of chemical activities and supported un-bundling processes. All of these firms remained small with typically 10 to 20 or even fewer employees.

The above typology of firms according to re-bundling practices shows that the recovery of the Bitterfeld-Wolfen chemical industry was not a straightforward process toward constructing a novel chemical industry agglomeration or cluster (e.g. Rosenfeld et al. 2007), but one with highly differentiated processes. The characterization of different firm types indicates that re-bundling initiatives were hardly radical in nature and were not able to offset the massive un-bundling processes that took place in the early years after Reunification. The next section synthesizes the diverse tendencies of corporate restructuring into a broader view of regional re-bundling prospects in the future.

\section{Conclusions: Un-bundling, Re-bundling and Regional Stagnation}

Building on a perspective that views regional restructuring processes after economic crises or ruptures as re-bundling processes (Bathelt and Boggs 2003; Bathelt 2009), this paper analyzes corporate responses in the Bitterfeld-Wolfen chemical and supplier industry to the transformations associated with Reunification in order to develop an aggregated perspective of possible regional development paths in the future (Figure 1). The concept of regional re-bundling is linked to an evolutionary perspective, but focuses on the investment and divestment processes that follow structural economic and/or political crises supporting a view that is forward-directed, instead of looking back. The concept draws attention to the actors and resources or assets, which are situated within a region or become available through relocations or investments and can be mobilized to anchor new or renewed technological trajectories locally. From this perspective, the paper clearly illustrates that the Bitterfeld-Wolfen chemical industry had to overcome drastic ruptures associated with changes in the political and economic system and failures in the privatization and economic integration processes that led to immediate radical un-bundling processes. Similar processes and challenges of restructuring also occurred in other industries and regions in East Germany and Eastern Europe (e.g. Land 2006; Pavlínek 2008). The effects of massive un-bundling processes, regional shrinkage and destruction of prior existing input-output linkages were similar to those in other East German industries and regions (Grabher and Stark 1997; Kollmorgen 2005). As Schmidt (1997) emphasized, the initial expectation that East 
German regions would just need a short-term trigger to develop self-sustained growth was clearly wrong in the case of Bitterfeld-Wolfen. This is reflected in the stagnating employment numbers in the East German chemical industry (Bathelt 2009), although an analysis of sales figures shows that the industry has recovered from the shock of Reunification and has continuously grown since the mid-1990s. East German sales of chemical products increased from $€ 6.6$ billion to $€ 20.3$ billion between 1995 and 2008, which is equivalent to an increase from 7.1 to $11.5 \%$ of overall German sales of the industry (Table 3).

[Insert Table 3 about here]

Massive un-bundling processes led to a partial destruction of former production resources and an out-migration of capital and labor to West German regions (Mitteldeutscher Rundfunk Online 2010). Although economic assistance and "ecological re-bundling" were combined with the federal "Aufbau Ost" program directing substantial amounts of investment capital into the region, this was not sufficient to reconstruct a large agglomeration of the chemical industry along with a fully-fledged support infrastructure. The policy of the federally-led Treuhandanstalt clearly provided an extra-burden on the re-bundling activities, limiting the possibilities to actively involve local/regional resources. Re-bundling processes that started later in Bitterfeld-Wolfen were never strong enough to make up for the former un-bundling processes or establish triggers to support more radical re-bundling. The processes were segmented, remained insular and did not form a consistent base for further complementary investment activities. Given the amount of initial destruction and un-bundling, however, we should exercise care in our critique. Given the state of East German industries and over-capacities in worldwide chemical production, markets in East Germany could have been easily supplied externally without their own production core. However, the research presented in this paper found substantial evidence of re-bundling processes in the Bitterfeld-Wolfen region, which show how firms and agents were able to mobilize resources, reconfigure existing production facilities and generate new production (Table 2):

Some regional plants were acquired by West German chemical firms and integrated into their national and international production and distribution networks (type 1a). Although these facilities had strong corporate loyalties and developed few regional linkages, they played an important role for the regional labor market. Operations which were acquired by foreign multinational firms made greater regional commitments in terms of linkages, although they were 
also bound to corporate loyalties (type 1b). Comparatively few management buy-ins or buy-outs (type 2) occurred in more knowledge-intensive segments of the former Kombinate, but stagnated or had difficulty surviving. Similarly, relatively few new innovative start-ups were launched (type 3). They remained small niche operations that struggled to achieve market legitimacy and were negligible in terms of their overall regional impact. Investments of small and medium-sized firms from West Germany and other countries tended to have the strongest regional effects, relative to the size of their investments (type 4). They had a stronger commitment toward the local labor market and supplier networks. Activities of new firms in environmental technologies (type 5) and in supplier and service sectors (type 6) initially developed quickly, but remained limited in their regional impact and did not trigger innovation.

Overall, it can be concluded that regional and federal policies and failed privatization activities were not able to stimulate self-sustained growth in the Bitterfeld-Wolfen chemical industry (e.g. Thomas 2005), which had been so dominant in the post-World War II period in East Germany. As suggested by Bathelt (2009: 376), a regional industry configuration developed that is strongly outward-looking with little internal "glue" - not a structure that could be described as a vibrant industry cluster. Nonetheless, firm-specific and political actions were able to mobilize new resources for investments and a reorientation of production activities in the chemical industry. After an initial period of massive regional un-bundling, the region experienced a broad scope of re-bundling activities, which was not to be expected in the chemical industry at that time. Even in an industry context of global restructuring, most corporate re-bundling activities were successful and resulted in durable and competitive firm structures. Due to the problematic nature of much of the prior production activities in the region, the re-bundling activities were, however, not able to make up for the initial massive losses in plants, jobs and resources after Reunification. It also turned out to be difficult to establish new networks and linkages between the new activities that could have produced wider regional multiplier effects (see, also, Graf and Henning 2009). As the epilog demonstrates, however, corporate re-bundling activities were able to mobilize economic and political initiatives and networks that stretched beyond the chemical industry, due to the role of economic leader and other elites who engaged actively in these processes. 


\section{Epilog: Beyond Corporate Re-bundling: Network Builders and Political Networks}

As the research in this project clearly indicated, the above studied corporate re-bundling processes and their regional effects were strongly influenced and guided by certain individuals that acted as economic leaders, network builders or "altruistic managers" in trying to motivate others to engage in joint regional projects and visions for a brighter regional future. As analyses of such local elites have shown, certain key individuals can become role models through their decisions and actions, by generating a regional spirit regarding economic development or by mobilizing others to participate in re-bundling activities (e.g. Geißel et al. 2003). Aside from other factors, regional and corporate re-bundling are thus closely linked to the activities of lead individuals, or the lack thereof. In Bitterfeld-Wolfen, such involvement was of utmost importance as corporate re-bundling processes were otherwise limited.

Considering the disastrous economic situation that had developed in the post-World War II period (Mitteldeutscher Rundfunk Online 2010), it would have been unrealistic to expect the development of a "blooming economic landscape"16 in the region. In fact, re-bundling processes and new initiatives were only possible because of the engagement of new political and economic leaders in the development of visions, plans and programs for reconstruction. Such processes were strongly supported and led by "altruistic managers" and "network builders" who had a high credibility among the labor force, political leadership and regional population. Some of them had worked in the region's chemical industry for most of their life, while others moved to the region after Reunification. All identified themselves with the region and its economy, participated in regional discussion circles, contributed actively to regional planning and employment initiatives, and spoke vividly to firms and managers from other parts of Germany and the world about the region. They felt committed to contribute to the reconstruction of the regional economy and took

${ }^{16}$ The German Chancellor Helmut Kohl used this metaphor after Reunification creating the expectation that East Germany would quickly develop into a prosperous economy. When it became clear that this was neither a fast nor an automatic process, East Germans viewed this as a broken promise and frustration grew. 
an active leadership role, way beyond their role as industrial managers. ${ }^{17}$ The list of individuals provided below is neither exhaustive, nor have these individuals been equally important in the rebundling process. They can be viewed as part of a first generation of post-Reunification leaders that shaped economic strategies, public policies and debates. Now that most of them have retired or are close to retirement, it will be interesting to see how these individuals will be replaced by a second generation of leading entrepreneurs and managers. The four managers identified below represent different roles in this process ranging from initiating economic investments and regional support policies through networking and creating new linkages with external firms:

- Georg Frank. He was the executive of Bayer Bitterfeld since 1997. Although born in Baden-Württemberg in West Germany, he grew to like the region and viewed it as his "life task" to actively contribute to the region's economic recovery. He was involved in virtually every important discussion round and economic or planning initiative in the region - be in the context of economic recovery, regional development or in his engagement with the regional industry association. He was the main individual heading Bayer's involvement in the region and participated in all sorts of initiatives that strengthened regional adaptability and ongoing re-bundling. In 2003, his active leadership in the region was acknowledged by the University of Halle, which rewarded him with an honorary professorship in economic chemistry. Georg Frank retired in 2005 (Europaticker 2005).

- Max Bräutigam. He was originally a manager of the Treuhandanstalt, responsible for splitting up and privatizing the former Kombinate in Bitterfeld and Wolfen, or parts thereof. After becoming increasingly unhappy with the nature of the restructuring process, he took over the firm CBW Chemie GmbH Bitterfeld-Wolfen in 1997 for about $€ 510,000$. He had already run the firm as Treuhandanstalt manager and was familiar with its structures and processes (Emr 2002). ${ }^{18}$ As manager, he stabilized the firm's situation in a stepwise manner

\footnotetext{
${ }^{17}$ Each of these individuals was interviewed several times over the course of this research project. They were selected here because they were regularly identified by the respondents during interviews, as well as in the media.

${ }^{18}$ For a while, the European Union Commission and the office of the district attorney in Halle undertook investigations whether this sale went along with the unjustified acquisition of state subsidies (Spiegel 1998).
} 
through a series of investment projects in upgrading and modernization. As such, this case became a role model of redeploying existing resources and modernizing traditional firm structures, strengthening incremental re-bundling processes.

- Günter Langner. He was originally a manager in the research facilities of the former Kombinat and felt committed to actively support the economic restructuring process in the region. He was active in attempts to establish a closed, integrated chemical park in Bitterfeld-Wolfen with unified governance, control and service provision, and was a critic of the final decision for an open-access industrial park (Mitteldeutsche Zeitung 1999). Although he later worked for Bayer in Leverkusen, West Germany, he felt closely tied to the region and returned after retirement to become active in a number of regional business ventures. Although not all locals might know much about his activities, he was involved in regional re-bundling in many ways: as a manager involved in the design of the chemical industry park, as a local entrepreneur and as a network builder drawing attention to the region.

- $\quad$ Manfred Kressin. He was the director of the technology incubator TGZ in Wolfen until his retirement in 2008 (Krüger 2008). Having originally lived in the region and worked in the Filmfabrik Wolfen before Reunification, he became mayor of the village Thalheim after Reunification (Uken 2006). He was strongly involved in the restructuring of the former Filmfabrik and the establishment of the TGZ. According to several respondents, Manfred Kressin was a well-respected home-grown with credibility in the region. He actively fought to create prospects for future economic development and for people to make a living. His actions could contribute to more radical re-bundling activities in the future, yet, as pointed out below, global competition might not allow for higher regional multiplier and job creation effects.

As a consequence of the engagement of these and other individuals, close cooperation developed between regional firms, industry associations and government and planning offices. Joint activities included a broad array of fields from environmental protection and renaturation to economic support and education and training programs for the youth. This led to the formation of wider political networks in the region.

Some notable success that was strongly supported by personal networks of political and economic leaders can be seen in the development of a new solar cell and photovoltaic industry 
that took a foothold in the region. In 2001, Q.Cells - a producer of high-end solar cells established a production facility near the chemical industry park in Thalheim for about 200 employees. The production activities were remotely connected to competencies that existed in the region, but local supplier and customer linkages were weak (Unicepta Abels \& Partner 2002; 2005). Interestingly, Manfred Kressin - in his role as mayor of Thalheim - played an important role in the original location decision of the firm (Uken 2006). Due to its success, Q.Cells attracted other producers to establish branch operations in the Bitterfeld-Wolfen region (Kappler 2008), thus contributing to significant employment growth. The solar cell industry created about 800 jobs by 2006 and 3000 by 2012 (Schlandt 2010; 2012). These activities were able to offset some of the still ongoing job losses in the region's chemical industry.

Overall, this has created a broader economic basis, with new prospects for potential future growth and a new regional development path. At the same time, however, this industry appears somewhat volatile and vulnerable to low-cost competition from East and Southeast Asia (Frankfurter Rundschau 2011). Related to increasing competition and decreasing state subsidies for solar energy, Q.Cells - like other German firms in the industry - ran into severe problems and had to file for bankruptcy in April 2012 (Schlandt 2012). This turmoil in the industry has opened up the regional development trajectory once again. Although it appears unclear what the future of solar cell production in Bitterfeld-Wolfen will be and in which way former jobs and facilities will continue to exist, regional re-bundling processes after Reunification in the region's chemical industry were successful to the extent that they provided a relatively stable economic base and ideal-type examples of how local initiatives can be mobilized and combined with external resources to produce the foundations for new rounds of capital accumulation.

\section{Acknowledgements}

This paper was prepared for the 2010 conference on "European Integration: Past, Present and Future" at Wilfrid Laurier University, Canada, organized by the International Migration Research Centre, the Rimini Centre for Economic Analysis and the Viessman European Research Centre. Many thanks are due to Ute Hirsch and Günter Langner for their help in making contact with key individuals in the Bitterfeld-Wolfen chemical industry, and to Heiner Depner, Katrin Kappes (formerly Griebel), Frank Kobiela and Caroline von Bernuth (formerly Jentsch) for their superb research support. Special thanks are due to three anonymous Reviewers and the Editors in 
proving comments that substantially helped to strengthen the conceptual basis of what was originally designed as an empirical paper. I also wish to thank Gerhard Braun, Alfred Hecht, Sebastian Henn, Andrew Munro, Josef Nipper, Kristina Schulz and Michael Seidel for valuable comments on earlier versions of this paper. Finally, I would like to thank my former students from seminars at the universities of Frankfurt/Main and Marburg who participated in field trips to the Bitterfeld-Wolfen region and helped to conduct some of the interviews that informed this research.

\section{References}

Albach, H. (1993) Zerrissene Netze. Eine Netzwerkanalyse des ostdeutschen Transformationsprozesses (Ruptured networks in East German transformation). Edition Sigma - Bohn, Berlin.

Barley, S.R. and P.S. Tolbert (1997) Institutionalization and structuration: studying the links between action and institution. Organization Studies 18.1, 93-117.

Bathelt, H. (1995) Global competition, international trade and regional concentration: the case of the German chemical industry during the 1980s. Environment and Planning C - Government and Policy 13.4, 395-424.

Bathelt, H. (2009) Re-bundling and the development of hollow clusters in the East German chemical industry. European Urban and Regional Studies 16.4, 363-381.

Bathelt, H. and J.S. Boggs (2003) Towards a reconceptualization of regional development paths: is Leipzig's media cluster a continuation of or a rupture with the past? Economic Geography 79.3, 265-293.

Bathelt, H., H. Depner and K. Griebel (2004) Chemische Industrie: Integrierte Standorte im Wandel (Chemical industry: restructuring of integrated production sites). In LeipnitzInstitut für Länderkunde (eds.), Nationalatlas Bundesrepublik Deutschland. Band 8: Unternehmen und Märkte (National atlas of Germany. Vol. 8: Firms and markets). Elsevier, München, pp. 68-71.

Bathelt, H., A.K. Munro and B. Spigel (2010) Challenges of transformation: innovation, rebundling and traditional manufacturing in Canada's Technology Triangle. Paper presented at the annual meetings of the Association of American Geographers, April 1418, Washington, DC. 
Becker, W. (1995) Chemiepark Bitterfeld ist noch ein Flickenteppich (Chemical park Bitterfeld is still like a patchwork blanket). Frankfurter Rundschau, October 10, p. 15.

Borsdorf, H., C. Opp and J. Stach (1993) Untersuchungen zur Kontamination von Wald-, Wiesen- und Ackerböden mit ausgewählten Organika in der Muldenaue bei Bitterfeld (Contamination of the Mulde flood plains near Bitterfeld). Chemische Technik 45.6, 467474.

Boschma, R. and K. Frenken (2011) Technological relatedness and regional branching. In H. Bathelt, M.P. Feldman and D.F. Kogler (eds.), Beyond territory: dynamic geographies of knowledge creation, diffusion, and innovation. Routledge, London, pp. 64-81.

Boschma, R.A. and J.G. Lambooy (1999) Evolutionary economics and economic geography. Journal of Evolutionary Economics 9.4, 411-429.

Boyer R. (1990) The regulation school: a critical introduction. Columbia University Press, New York.

Boyer R. (2000) The political in the era of globalization and finance: focus on some régulation school research. International Journal of Urban and Regional Research 24.2, 274-322.

Brückner, H., K.D. Spona and R. Gerlach (1993) Untersuchungen zur Umweltbelastung (Schwermetalle) im Kreis Merseburg, Sachsen-Anhalt (Analysis of heavy metal concentrations in Merseburg county, Sachsen-Anhalt). In U. Radtke (ed.), Schwermetalle (Heavy metals). Department of Geography, University of Düsseldorf, Düsseldorf, pp. 67-79.

Bundesanstalt für vereinigungsbedingte Sonderaufgaben (1997) Umstrukturierung der ostdeutschen Großchemie: Der schwierige Weg in die Zukunft (Restructuring of the East German chemical industry: difficult path into the future). BvS, Berlin.

Bühler, C. (1999) Soziale Netzwerke von Unternehmensgründungen in Ostdeutschland (Social networks of start-ups firms in East Germany). In D. Bögenhold (ed.), Unternehmensgründungen und Dezentralität: Renaissance der beruflichen Selbständigkeit in Europa? (Start-up firms and decentralized structure). Westdeutscher Verlag, Opladen \& Wiesbaden, pp. 195-220.

Chapman, K. (2005) From "growth centre" to "cluster": restructuring, regional development, and the Teesside chemical industry. Environment and Planning A 37.4, 597-615.

Chapman, K., D. MacKinnon and A. Cumbers (2004) Adjustment or renewal in regional clusters? A study of diversification amongst SMEs in the Abdeen oil complex. Transactions of the Institute of British Geographers NS 29.3, 382-396. 
Chemie AG Bitterfeld-Wolfen (1993) Bitterfelder Chronik: 100 Jahre Chemiestandort BitterfeldWolfen (The Bitterfeld chronicle: 100 years of chemical production). Dresden.

Chemie-Produktion (1996) Agieren zwischen 'Kolossen' (Acting between giants). 96.6, p. 24-25. Denecke, M. (1994) Milliarden fürs Revier (Billions for the region). gp magazin, 94.5, p. 15.

Derlien, H., T. Faupel and C. Nieters (1999) Industriestandort mit Vorbildfunktion? Das ostdeutsche Chemiedreieck (The East German chemical triangle as a role model?). Discussion Papers FS IV 99-16, Wissenschaftszentrum Berlin für Sozialforschung, Berlin. Dühr, S. (1998) Nachhaltige Regionalentwicklung als Leitbild für altindustrialisierte Regionen? Die Umstrukturierung von Altindustriestandorten in der Region Bitterfeld-Wolfen (Restructuring of old industrial locations in the Bitterfeld-Wolfen region). Zentrum für Europäische Studien, Universität Trier, Trier.

Emr, A. (2002) Multipurpose-Anlagen planen (Multi-purpose facility design). CAV, 2002.4, pp. 18 and 21.

Europaticker (2005) Neuer Geschäftsführer der Bayer Bitterfeld GmbH (New executive of Bayer Bitterfeld GmbH). 669.

Faupel, T., C. Nieters and H. Derlien (2001) Chemieparks als innovative Strategie? Analyse des Strukturwandels in der Region Bitterfeld-Wolfen/Schkopau/Leuna (Chemical industry parks as an innovative strategy? Structural change in the BitterfeldWolfen/Schkopau/Leuna region). Geographische Rundschau 53.3, 31-36.

Feldman, M. and J.L. Francis (2006) Entrepreneurs as agents in the formation of industrial clusters. In B. Asheim, P. Cooke and R. Martin (eds.), Clusters and regional development: critical reflections and explorations. Routledge, London \& New York, pp. 115-136.

Frankfurter Rundschau (1994) Hauri sagt endgültig ab - Belegschaft ist empört (Hauri cancels - Labour force is in anger). May 3, p. 15.

Frankfurter Rundschau (2001) Rückzieher aus Bitterfeld (Backdown from Bitterfeld). November 5, p. 10.

Frankfurter Rundschau (2011) Q.Cells verlagert Produktion (Q.Cells relocates production). August 11, p. 15.

Geißel, B., K. Pähle and H. Sahner (eds.) (2003) Lokale politische Eliten (Local Political Elites). Sonderforschungsbereich 580 "Gesellschaftliche Entwicklungen nach dem Systemumbruch. Diskontinuität, Tradition und Strukturbildung”, University of Jena, Jena. 
Giblin, M. (2011) Managing the global-local dimensions of clusters and the role of "lead" organizations: the contrasting cases of the software and medical technology clusters in the West of Ireland. European Planning Studies 19.1, 23-42.

Grabher, G. (1993) The weakness of strong ties: the lock-in of regional development in the Ruhr area. In G. Grabher (ed.), The embedded firm: on the socioeconomics of industrial networks. Routledge, London \& New York, pp. 255-277.

Grabher, G. and D. Stark (1997) Organizing diversity: evolutionary theory, network analysis and Postsocialism. Regional Studies 31.5, 533-544.

Graf, H. and T. Henning (2009) Public research in regional networks of innovators: a comparative study of four East German regions. Regional Studies 43.10, 1349-1368.

Greco, L. (2004) Industrial redundancies: a comparative analysis of the chemical and clothing industries in the UK and Italy. Ashgate, Aldershot.

Günther, J. and O. Gebhardt (2005) Eastern Germany in the process of catching up the role of foreign and West German investors in technological renewal. Eastern European Economics $43.3,78-102$.

Haase, H.E. (1984) Die Wirtschaft der DDR (The economy of the German Democratic Republic). Geographische Rundschau 36.12, 632-638.

Hannan, M.T. and J. Freeman (1984) Structural inertia and organizational change. American Journal of Sociology 49.2, 149-164.

Hassink, R. (2005) How to unlock regional economies from path dependency? From learning region to learning cluster. European Planning Studies 13.4, 521-535.

Hertle, H.-H. (2001) Der kostspielige Leuna-Deal (The costly Leuna deal). Frankfurter Rundschau, February 3, p. 17.

Hirsch, J. (1990) Kapitalismus ohne Alternative? (Capitalism without alternative?) VSA, Hamburg.

Kaiser, M. (1994) Weißstorch in Bitterfeld (White storks in Bitterfeld). Frankfurter Rundschau, November 19, p. ZB1.

Kappler, R. (2008) Former East Germany gains solar boost. Renewable Energy Focus 9.3, 68-70.

Kirchner, P. (2000) The German-owned manufacturing sector in the North-East of England. European Planning Studies 8.5, 601-617.

Kollmorgen, R. (2005) Ostdeutschland: Beobachtungen einer Übergangs- und Teilgesellschaft (East Germany: Observations of a transition and fragment society). VS Verlag, Wiesbaden. 
Krüger, C. (2008) Neuer Mann hat jetzt im TGZ das Sagen (New man in command in TGZ). Mitteldeutsche Zeitung, July 18.

Land, R. (2006) Fragmentierte Wirtschaftsstrukturen zwischen Deindustrialisierung, Stagnation und Innovation (Fragmented economic structures between deindustrialisation, stagnation and innovation). Berliner Debatte Initial 17.5, 27-38.

Mahoney, J. and J.R. Pandian (1992) The resource-based view within the conversation of strategic management. Strategic Management Journal 13.5, 363-380.

Malecki, E.J. (2009) Geographical environments for entrepreneurship. International Journal of Entrepreneurship and Small Business 7.2, 175-190.

Martin, R. (2010) The 2009 Roepke Lecture in Economic Geography - Rethinking regional path dependence: from lock-in to evolution. Economic Geography 86.1, 1-27.

Martin, R. and P. Sunley (2006) Path dependence and regional economic evolution. Journal of Economic Geography 6.4, 395-437.

Martin, R. and P. Sunley (2011) Conceptualizing cluster evolution: beyond the life cycle model? Regional Studies 45.10, 1299-1318.

Maskell, P. (2001) The firm in economic geography. Economic Geography 77.4, 329-344.

Mitteldeutscher Rundfunk Online (2010) Der Wandel in Ostdeutschland: Bitterfeld-Wolfen heute (The change in East Germany: Bitterfeld-Wolfen today). April 12 (URL: http://www.mdr.de/).

Mitteldeutsche Zeitung (1999) Frühlingserwachen mit neuen Aufträgen in alten Anlagen (Spring awakening with new contracts in old plants). February 18.

Neffke, F., M. Henning and R. Boschma (2011) How do regions diversify over time? Industrial relatedness and the development of new growth paths in regions. Economic Geography $87.3,237-265$.

Nonaka, I., R. Toyama and A. Nagata (2000) A firm as a knowledge-creating entity: a new perspective on the theory of the firm. Industrial and Corporate Change 9.1, 1-20.

Oelke, E. (1998) Das Verdichtungsgebiet Halle-Leipzig (The Halle-Leipzig agglomeration). In E. Kulke (ed.), Wirtschaftsgeographie Deutschlands (Economic geography of Germany). Klett-Perthes, Gotha \& Stuttgart, pp. 381-405.

Orlikowski, W.J. (2000) Using technology and constituting structures: a practice lens for studying technology in organizations. Organization Science 11.4, 404-428. 
Owen-Smith, J. and W.W. Powell (2004) Knowledge networks as channels and conduits: the effects of spillovers in the Boston biotechnology community. Organization Science 15.1, 221.

Pavlínek, P. (2008) A successful transformation? Restructuring of the Czech automobile industry. Physica, Heidelberg.

P-D ChemiePark Bitterfeld Wolfen GmbH (2002) Die Chemie stimmt! ... im Chemiedreieck mitten in Europa (The chemistry works! ... in the chemical industry triangle in the middle of Europe). Bitterfeld.

Penrose, E. (1959) The theory of the growth of the firm. Oxford University Press, Oxford.

Petelet-Giraud, E., P. Négrel, L. Gourcy, C. Schmidt and M. Schirmer (2007) Geochemical and isotopic constraints on groundwater-surface water interactions in a highly anthropized site. The Wolfen/Bitterfeld megasite (Mulde subcatchment, Germany). Environmental Pollution $148.3,707-717$.

Rigby, D.L. and J. Essletzbichler (1997) Evolution, process variety, and regional trajectories of technological change in U.S. manufacturing. Economic Geography 73.3, 269-284.

Rosenfeld, M., P. Franz and G. Heimpold (2007) Economic 'clusters' in East Germany: evidence on the location and characteristics of spatially concentrated industries. Post-Communist Economies 19.1, 73-92.

Rupieper, H.-J., F. Sattler and G. Wagner-Kyora (eds.) (2005) Die mitteldeutsche Chemieindustrie und ihre Arbeiter im 20. Jahrhundert (The Central German chemical Industry and its workers in the 20th century). Halle, Mitteldeutscher Verlag.

Schlandt, J. (2010) Trügerischer Solarboom (Delusive solar boom). Frankfurter Rundschau, May 31, pp. 14-15.

Schlandt, J. (2012) Schatten über Bitterfeld (Shaddow over Bitterfeld). Frankfurter Rundschau, April 4, pp. 2-3.

Schmid, K.-P. (2000) Phoenix aus dem Russ (Like a Phenix from the ashes). Die Zeit, September 28 , p. 25.

Schmidt, R. (1997) Viele ostdeutsche Betriebe leiden noch heute unter Phantomschmerzen (Many East German firms suffer from phantom pain). Frankfurter Rundschau, April 11, p. 18.

Schwartau, C. (1980) Die chemische Industrie in der DDR - Renaissance einheimischer Rohstoffe durch Beschränkung der Erdölimporte? (The chemical industry in the German 
Democratic Republic - Renaissance of national resources due to limitations on oil imports?). Wochenbericht des DIW 80.47, 485-490.

Schwartau, C. (1987) Umweltprobleme in einem alten Industrierevier - der Ballungsraum HalleLeipzig (Environmental problems in an old industrialized region - The agglomeration Halle-Leipzig). Geographische Rundschau 39.11, 628-632.

Schwartau, C. (1989) Die chemische Industrie in der DDR - Wachstum in konservativen Strukturen (The chemical industry in the German Democratic Republic - Growth in conservative structures). Wochenbericht des DIW 89.41, 498-504.

Scott, A.J. (1998) Regions and the world economy: the coming shape of global production, competition, and political order. Oxford University Press, Oxford \& New York.

Simmie, J. and R. Martin (2010) The economic resilience of regions: towards an evolutionary approach. Cambridge Journal of Regions, Economy and Society 3.1, 27-42.

Spiegel (1990) "Die Leute werden dumm im Kopf” ("The people get dumb in their heads"). 1990.2, pp. 35-46.

Spiegel (1998) Verdacht in Brüssel (Suspicion in Brussels). 1998.8.

Storper, M. and R. Walker (1989) The capitalist imperative. territory, technology, and industrial growth. Basil Blackwell, New York \& Oxford.

Thomas, M. (2003) Neue Selbständige in Ostdeutschland - ein soziales Phänomen quer zur Transformationslogik? (New entrepreneurs in East Germany - A social phenomenon at odds with the transformation logic?). In M. Brussig, F. Ettrich and R. Kollmorgen (eds.), Konflikt und Konsens: Transformationsprozesse in Ostdeutschland (Conflict and Concensus: Transformation Processes in East Germany). Leske + Budrich, Opladen, pp. 49-80.

Thomas, M. (2005) Ostdeutscher Stillstand versus ungleichzeitige Lernprozesse Transformationsmodus und Innovationsblockaden (Stagnation versus non-simultaneous learning in East German transformation). In R. Kollmorgen (ed.), Transformation als Typ sozialen Wandels: Postsozialistische Lektionen, historische und interkulturelle Vergleiche (Transformation as a form of social change: post-socialist lectures and historical and intercultural comparisons). Lit, Münster, pp. 95-110.

Topel, T. (1984) Energie- und Industriezentren in der DDR (Energy and industrial centers in the German Democratic Republic). Geographische Rundschau 36.12, 615-621.

Uken, M. (2006) Im Osten was Neues (Something new in the East). greenpeace magazin, 06.3. 
Unicepta Abels \& Partner (2002) Wir über uns: Unternehmungen im ChemiePark Bitterfeld Wolfen 2002 (We about us: firms in the chemical park Bitterfeld Wolfen 2002). Brochure, Bitterfeld, Unicepta Abels \& Partner.

Unicepta Abels \& Partner (2005) Wir über uns: Unternehmungen im ChemiePark Bitterfeld Wolfen 2005 (We about us: firms in the chemical park Bitterfeld Wolfen 2005). Brochure, Bitterfeld, Unicepta Abels \& Partner.

Verband der Chemischen Industrie (2006) Chemiewirtschaft in Zahlen - Ausgabe 2006 (Chemical economy in numbers - 2006 edition). Erhardt, Frankfurt/Main.

Verband der Chemischen Industrie (2009) Chemiewirtschaft in Zahlen - Ausgabe 2009 (Chemical economy in numbers - 2009 edition). Erhardt, Frankfurt/Main.

Wernerfelt, B. (1984) A resource-based view of the firm. Strategic Management Journal 5.2, 171-180.

Williamson, O.E. (1985) The economic institutions of capitalism: firms, markets, relational contracting. Free Press, New York.

Zeng, G. and H. Bathelt (2011) Divergent growth trajectories in China's chemical industry: the case of the newly developed industrial parks in Shanghai, Nanjing and Ningbo. GeoJournal 76.6, 675-698. 
Figure 1: Regional Development at the Crossroads: Diachronic Processes of Rupture and Re-bundling

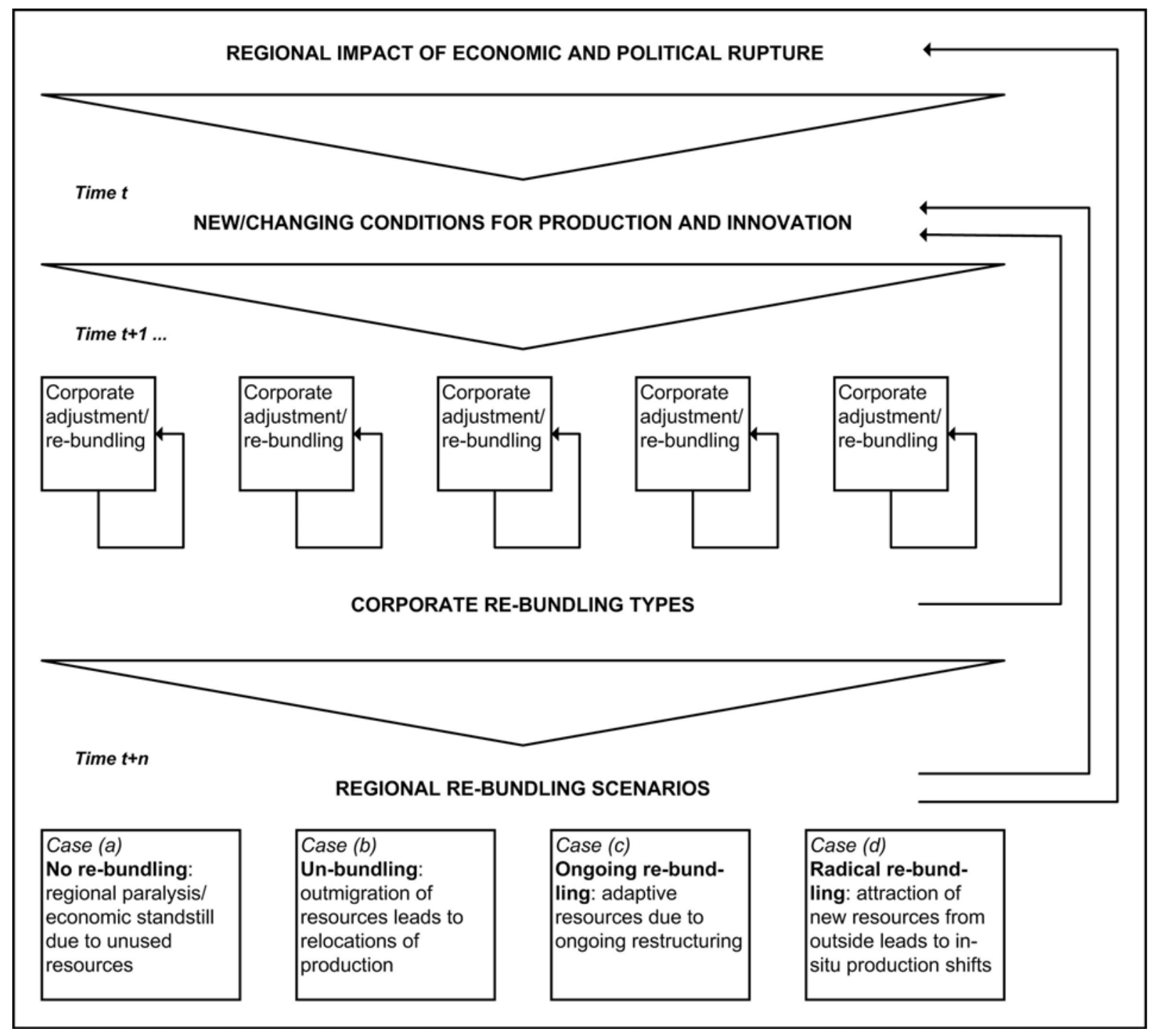


Table 1: Interviews by Firm Type Conducted in the Bitterfeld-Wolfen Chemical Industry, 1995-2006

Firm type

Number of firms

interviewed
Share of firms

interviewed

Type 1a: Acquisitions/investments by West

German chemical multinationals

5

$8 \%$

Type 1b: Acquisitions by foreign chemical

multinationals

9

$14 \%$

Type 2: Chemical management buy-ins or buy-

outs

11

$17 \%$

Type 3: Innovative chemical start-ups

7

$11 \%$

Type 4: Investments of small and medium-sized

West German chemical firms

4

$6 \%$

Type 5: Environmental clean-up and consulting

firms

6

$10 \%$

Type 6: Independent chemical service providers

21

$33 \%$

Total

63

$99 \%$ 
Table 2. Firm-specific and Regional Re-bundling Processes by Firm Type in the BitterfeldWolfen Chemical Industry, 1995-2006

\begin{tabular}{|c|c|c|}
\hline Firm type & Firm-specific re-bundling processes & $\begin{array}{l}\text { Prospects for regional re- } \\
\text { bundling }\end{array}$ \\
\hline $\begin{array}{l}\text { Type 1a: } \\
\text { Acquisitions/ } \\
\text { investments by } \\
\text { West German } \\
\text { chemical } \\
\text { multinationals }\end{array}$ & $\begin{array}{l}\text { - Few large investments providing access to } \\
\text { corporate resources and markets } \\
\text { - Little local decision-making competencies and } \\
\text { research activities } \\
\text { - Predominance of corporate networks and material } \\
\text { linkages }\end{array}$ & $\begin{array}{l}\text { - Limited regional producer-user } \\
\text { linkages } \\
\text { - Potential for radical re- } \\
\text { bundling not realized }\end{array}$ \\
\hline $\begin{array}{l}\text { Type } 1 \mathrm{~b} \text { : } \\
\text { Acquisitions by } \\
\text { foreign chemical } \\
\text { multinationals }\end{array}$ & $\begin{array}{l}\text { - Relatively few small/medium-sized investments } \\
\text { providing access to corporate resources and markets } \\
\text { - Some local decision-making and problem-solving } \\
\text { competencies } \\
\text { - Predominance of corporate networks, but attempt } \\
\text { to develop local suppliers }\end{array}$ & $\begin{array}{l}\text { - Some regional producer-user } \\
\text { linkages } \\
\text { - No radical re-bundling } \\
\text { - But impetus to strengthen } \\
\text { future ongoing re-bundling }\end{array}$ \\
\hline $\begin{array}{l}\text { Type 2: Chemical } \\
\text { management buy- } \\
\text { ins or buy-outs }\end{array}$ & $\begin{array}{l}\text { - Few, small such investments building on existing } \\
\text { strength } \\
\text { - Focus on stabilization/survival, not growth } \\
\text { - Too small to trigger growth in related industries }\end{array}$ & $\begin{array}{l}\text { - No growth triggers through } \\
\text { regional networks } \\
\text { - No broad re-bundling impetus; } \\
\text { instead un-bundling through } \\
\text { failures }\end{array}$ \\
\hline $\begin{array}{l}\text { Type 3: Innovative } \\
\text { chemical start-ups }\end{array}$ & $\begin{array}{l}\text { - Relatively few, small, innovative start-ups (hardly } \\
\text { production) } \\
\text { - Main goal to develop wider (global) markets } \\
\text { - Priority of careful growth over rapid expansion } \\
\text { - Hardly any production linkages }\end{array}$ & $\begin{array}{l}\text { - Sparse regional producer-user } \\
\text { linkages } \\
\text { - Too small to enfold radical re- } \\
\text { bundling potential }\end{array}$ \\
\hline $\begin{array}{l}\text { Type } 4 \text { : Investments } \\
\text { of small and } \\
\text { medium-sized West } \\
\text { German chemical } \\
\text { firms }\end{array}$ & $\begin{array}{l}\text { - Limited number of smaller investments focused } \\
\text { on existing/development of new competencies } \\
\text { - Initial investment projects generated further } \\
\text { investments } \\
\text { - Local decision-making and development activities } \\
\text { - Efforts to develop new supplier networks }\end{array}$ & $\begin{array}{l}\text { - Increasing regional producer- } \\
\text { user linkages } \\
\text { - Strengthening of ongoing re- } \\
\text { bundling activities through } \\
\text { durable relationships }\end{array}$ \\
\hline $\begin{array}{l}\text { Type 5: } \\
\text { Environmental } \\
\text { clean-up and } \\
\text { consulting firms }\end{array}$ & $\begin{array}{l}\text { - Fast growth of such activities after Reunification } \\
\text { - Investments unrelated to established/new firms } \\
\text { - No spill-overs to manufacturing in terms of new } \\
\text { product/process development } \\
\text { - Many firms left after clean-up completed } \\
\text { - Hardly any producer-user linkages }\end{array}$ & $\begin{array}{l}\text { - Hardly regional linkages in the } \\
\text { chemical industry } \\
\text { - Hardly innovation triggers } \\
\text { - No contribution to immediate } \\
\text { re-bundling } \\
\text { - Instead partial un-bundling } \\
\text { after clean-up } \\
\text { - But "environmental re- } \\
\text { bundling" }\end{array}$ \\
\hline $\begin{array}{l}\text { Type 6: Independent } \\
\text { chemical service } \\
\text { providers }\end{array}$ & $\begin{array}{l}\text { - Heterogeneous structure of supplier sector } \\
\text { - Large supplier operations had to scale down } \\
\text { - Original expectations of strong regional user } \\
\text { linkages not realistic }\end{array}$ & $\begin{array}{l}\text { - Contribution to both un- } \\
\text { bundling and ongoing re- } \\
\text { bundling } \\
\text { - No initial triggers for re- } \\
\text { bundling from suppliers }\end{array}$ \\
\hline
\end{tabular}


Table 3. Sales by Land in the East German Chemical Industry, 1995-2008 (Source: Verband der Chemischen Industrie 2006, pp. 32 and 36ff.; 2009, pp. 32 and 38ff.)

\begin{tabular}{|c|c|c|c|c|}
\hline \multirow[b]{2}{*}{ Land } & \multicolumn{4}{|c|}{ Sales in the chemical industry ( $€$ billion) } \\
\hline & 1995 & 2000 & 2005 & 2008 \\
\hline Berlin & 2.1 & 2.7 & 4.1 & 5.6 \\
\hline Brandenburg & 0.8 & 1.1 & 1.6 & 2.1 \\
\hline \multicolumn{5}{|l|}{ Mecklenburg- } \\
\hline Vorpommern & $0.2^{1)}$ & 0.4 & 0.5 & 1.1 \\
\hline Sachsen & 1.0 & 1.4 & 2.1 & 3.3 \\
\hline Sachsen-Anhalt & 2.1 & 3.6 & 4.8 & 6.8 \\
\hline Thüringen & $0.4^{1)}$ & 0.5 & 1.0 & 1.4 \\
\hline \multicolumn{5}{|l|}{ Subtotal East } \\
\hline Germany & 6.6 & 9.7 & 14.1 & 20.3 \\
\hline \multicolumn{5}{|l|}{ Share of German } \\
\hline total & $7.1 \%$ & $8.9 \%$ & $11.6 \%$ & $11.5 \%$ \\
\hline German total & 92.1 & 108.6 & 121.9 & 176.5 \\
\hline
\end{tabular}

